\title{
Chagas' disease and ageing: the coexistence of other chronic diseases with Chagas' disease in elderly patients
}

\author{
Doença de Chagas e envelhecimento: a associação de outras enfermidades \\ crônicas em pacientes idosos chagásicos
}

\author{
Rosalía Matera de Angelis Alves ${ }^{1}$, Raquel Prado Thomaz ${ }^{2}$ Eros Antônio de Almeida ${ }^{1}$, \\ Jamiro da Silva Wanderley ${ }^{1}$ and Maria Elena Guariento ${ }^{1}$
}

\begin{abstract}
This study aimed to identify the main comorbidities in elderly chagasic patients treated in a reference service and identify possible associations between the clinical form of Chagas' disease and chronic diseases. Ninety patients aged 60 years-old or over were interviewed and their clinical diagnoses recorded. The study population profile was: women (55.6\%); median age (67 years); married (51.1\%); retired (73.3\%); up to four years' education (64.4\%); and earning less than two minimum wages (67.8\%). The predominant forms of Chagas' disease were the cardiac (46.7\%) and mixed forms $(30 \%)$. There was a greater proportion of mild cardiac dysfunction $(84.1 \%)$, frequently in association with megaesophagus. The mean number of concurrent diseases was $2.856 \pm 1.845$, and $33 \%$ of the patients had four or more comorbidities. The most frequent were systemic arterial hypertension $(56.7 \%)$, osteoporosis (23.3\%), osteoarthritis (21.2\%) and dyslipidemia (20\%). Positive correlations were verified between sex and comorbidities and between age group and comorbidities.
\end{abstract}

Key-words: Chagas' disease. Ageing. Elderly. Comorbidities.

\section{RESUMO}

Este trabalho objetivou avaliar o perfil sociodemográfico e identificar as principais co-morbidades de idosos chagásicos, buscando associação entre forma clínica da doença de Chagas e enfermidades crônicas. Foi realizada entrevista e levantamento dos diagnósticos clínicos de 90 chagásicos com idade $\geq 60$ anos. Encontrou-se: mulheres (55,6\%), mediana de 67 anos, casados (51,1\%) e renda mensal inferior a dois salários-mínimos (67,8\%). A forma clínica predominante foi a cardíaca (46,7\%), seguida da mista (30\%). Houve maior proporção de cardiopatia leve $(84,1 \%)$, sendo frequente a associação com megaesôfago. Trinta e três por cento apresentavam quatro ou mais co-morbidades, dentre elas: hipertensão arterial (56,7\%), osteoporose (23,3\%), osteoartrite $(21,2 \%)$ e dislipidemia (20\%). Obteve-se correlação positiva entre gênero e co-morbidades, faixa etária e co-morbidades.

Palavras-chaves: Doença de Chagas. Envelhecimento. Idosos. Co-morbidades.

When vectorial and transfusional transmission of Chagas' disease is controlled, acute cases of the disease gradually cease to appear and the number of young people infected falls ${ }^{11}$. However, the challenge of treating millions of infected individuals during the chronic phase of the disease remains. A large proportion of these individuals are elderly and are therefore predisposed to other chronic conditions apart from Chagas' disease. In Brazil, 80\% of elderly individuals have at least one non-transmittable chronic disease and around 15\% have five or more ${ }^{1625}$. Furthermore, elderly individuals tend to have greater physiological and

\footnotetext{
1. Grupo de Estudos em Doença de Chagas, Departamento de Clínica Médica, Faculdade de Ciências Médicas, Universidade Estadual de Campinas, Campinas, SP. 2. Curso de Medicina, Faculdade de Ciências Médicas, Universidade Estadual de Campinas, Campinas, SP.

Endereço para correspondência: Dra. Rosalía M.A. Alves. Dept ${ }^{\underline{0}}$ de Clínica Médica/FCM/UNICAMP. R. Alexander Fleming 40, Cidade Universitária Zeferino Vaz, 13083-970 Campinas, SP, Brasil.

Tel: 55 193521-7878

e-mail: drarosa@fcm.unicamp.br

Rcebido para publicação em 14/05/2009

Aceito em 12/11/2009
}

immunological susceptibility, particularly to infection, which contributes to a reduction in their physical capacity and reduces their independence ${ }^{15}$.

Special emphasis should be given to the coexistence of Chagas' disease with the ageing process in people suffering from this condition. In light of the decline that occurs with advancing age, there may be specific aspects of the ageing process in Chagas' sufferers that need to be more clearly understood ${ }^{1126}$. On the one hand, these individuals bear the stigma of the disease ${ }^{13}$, as well the biological and psychosocial consequences ${ }^{1823}$ of the evolution of an endemic disease that affects the cardiac and digestive systems. There is evidence that heart failure (HF) in most elderly chagasic patients is caused by cardiac changes typical of ageing, together with other diseases of the heart and circulatory system ${ }^{12}{ }^{19}$. However, according to Rocha et $\mathbf{l}^{47}$, elderly chagasic patients without advanced cardiac dysfunction have good functional health, similar to that of young chagasic patients at the same clinical stage.

The fact that chronic diseases often coexist results in patients making heavy use of health services and medication and, consequently, at risk of practicing polypharmacy, a condition 
defined as the use of one medication to correct the adverse effect of another one and/or daily use of five or more medications per individual $^{3103252}$. In light of this, the combination of Chagas' disease and other illnesses may increase morbidity and mortality and lead to a reduction in the quality of life in these elderly patients ${ }^{124}$. The aim of this study was to identify the principal comorbidities in elderly chagasic patients being treated in a reference service and to determine their sociodemographic profile, as well as establish whether an association exists between the clinical form of the disease and other chronic illnesses and whether this depends on sex and age.

\section{MATERIAL AND METHODS}

This study was conducted in the Outpatient Unit of the Group for Studies into Chagas' Disease (GEDoCh), Clinic Hospital of Campinas State University (HC/UNICAMP), and approved by the Research Ethics Committee of the Faculty of Medical Sciences, Campinas State University (n: 124599). The study population consisted of 90 men and women aged 60 years-old or over who were positive for Chagas' disease in at least two serological tests. Patients with inconclusive serology, cognitive alterations or clinical decompensation were not included in the study. A questionnaire was prepared to determine the sociodemographic profile of the study population using other instruments cited in the literature ${ }^{25} 2627$. Data was collected from February 2007 to October 2007 in face-to-face interviews after the patients' appointments, which had been previously scheduled. Clinical data were collected from the patients' medical records.

The chronic forms of Chagas' disease had been previously classified as indeterminate, cardiac, digestive and mixed (i.e., cardiac and digestive, with the presence of megaesophagus and/or megacolon). This classification complies with the criteria defined by the World Health Organization/Pan American Health Organization (WHO/PAHO), which are used to determine whether cardiac dysfunction is present and to classify its severity according to the following different grades of involvement of the disease ${ }^{38}$.

Grade 1, chagasic infection without clinical, radiological or electrocardiographic indicators of cardiac lesions;

Grade 2, moderate or no symptoms; normal X-rays, or X-rays indicating mild cardiac hypertrophy; abnormal electrocardiogram (ECG), e.g., a complete right-branch bundle block $(\mathrm{RBBB})$, changes in ventricular repolarization and ventricular extrasystoles;

Grade 3, evident symptoms, moderate cardiac hypertrophy and changes in the ECG, such as RBBB with a shift in the mean cardiac electrical axis and regions of electrical inactivity;

Grade 4, very pronounced symptoms including heart failure; $\mathrm{X}$ ray examination reveals advanced cardiomegaly and the ECG shows severe, multiple abnormalities, such as complex arrhythmias and extensive regions of electrical inactivity.

Based on this classification, the cardiac form of Chagas' disease was further divided into mild or serious. The mild form is considered to be present in individuals who satisfy the criteria used to define WHO/PAHO grades 1 and $2^{38}$, while for the serious form, individuals must have the characteristics dertermined for grades 3 and 4 .

For the statistical analysis, the Chi square and Fisher exact tests were used to determine whether there was an association between the variables being studied. When required, the Student $\mathrm{t}$ test was used for normal distributions and the Mann Whitney test in all other cases. The Epi Info program (version 6.04d) was used, with a significance level of $\mathrm{p}<0.05$.

\section{RESULTS}

The majority (55.6\%) of the interviewees were women; $70 \%$ were between 60 and 69 years of age; the median age was 67 years-old (mean $67.7 \pm 6.5$ ); $73.3 \%$ were retired; $64.4 \%$ had only attended school for up to four years; and $67.8 \%$ had a monthly income of less than two minimum monthly wages. A relatively high percentage of them were found to be illiterate $(30 \%)$, the majority were married (51.1\%) and almost $30 \%$ were widows or widowers. The predominant clinical form of Chagas' disease was the cardiac form (46.7\%), followed by the mixed (30\%), digestive (13.3\%) and indeterminate (10\%) forms. Of the individuals with cardiac dysfunction, $84.1 \%$ and $15.9 \%$ presented with the mild and serious forms, respectively. Of those with the digestive form of the disease, $58.3 \%$ were suffering from megaesophagus, $16.7 \%$ from megacolon and $25 \%$ from both complications together. For the mixed form, the predominant combination was cardiac dysfunction and megaesophagus (48.1\%).

Among females, a similar distribution was verified for both the mixed (36\%) and cardiac (34\%) forms of the disease. A higher incidence of the cardiac form (62.5\%) was veried among elderly men. The digestive and indeterminate forms predominated among women, with no statistically significant difference observed between the distribution of either form $(\mathrm{p}=0.169487)$. In subjects under the age of 67 years-old, the cardiac (51.9\%), digestive (15.4\%) and indeterminate (13.5\%) forms predominated. In those aged 67 years-old or over, there was a greater $(44.7 \%)$ proportion of the mixed form (Table 1).

In the individuals interviewed, an average of $2.8 \pm 1.8$ illnesses were present together with Chagas' disease. The groups were divided into two categories according to the number of comorbidities: those with less than four $(66.7 \%)$ and those with equal to or more than four $(33.3 \%)$. With regard to the type of concurrent chronic disease, the following were most observed: systemic arterial hypertension (SAH) (56.7\%), osteoporosis (23.3\%), osteoarthritis (21.2\%), dyslipidemia (20\%), ischemic heart disease, diabetes mellitus (DM) and dyspepsia in equal proportions (10\%), as well as $\mathrm{HF}$ and hypothyroidism, which had an incidence of $7.78 \%$ each (Table 2). Other diagnoses were made in smaller proportions: depressive disorders (6.7\%), chronic venous insufficiency (6.1\%), obesity $(5.6 \%)$, cerebrovascular disease $(4.4 \%)$, cataracts (4.1\%) and chronic obstructive pulmonary disease (3.3\%).

The number and type of comorbidities varied according to sex. A higher incidence of women with up to four comorbidities 
TABLE 1

Distribution of the clinical form of Chagas' disease in elderly chagasic patients interviewed in the GEDoCh Outpatient Unit according to sex, age group, level of education and income.

\begin{tabular}{|c|c|c|c|c|c|c|c|c|}
\hline \multirow[b]{3}{*}{ SD variables } & \multicolumn{8}{|c|}{ Clinical Form of Chagas' disease } \\
\hline & \multicolumn{2}{|c|}{ indeterminate } & \multicolumn{2}{|c|}{ cardiac } & \multicolumn{2}{|c|}{ digestive } & \multicolumn{2}{|c|}{ mixed } \\
\hline & $\mathrm{n}$ & $\%$ & $\mathrm{n}$ & $\%$ & $\mathrm{n}$ & $\%$ & $\mathrm{n}$ & $\%$ \\
\hline \multicolumn{9}{|l|}{ Sex } \\
\hline male & 3 & 7.5 & 25 & 62.5 & 3 & 7.5 & 9 & 22.5 \\
\hline female & 6 & 12.0 & 17 & 34.0 & 9 & 18.0 & 18 & 36.0 \\
\hline \multicolumn{9}{|l|}{ Age group } \\
\hline$\leq 67$ years-old & 7 & 13.5 & 27 & 51.9 & 8 & 15.4 & 10 & 19.2 \\
\hline$>67$ years-old & 2 & 5.3 & 15 & 39.5 & 4 & 10.5 & 17 & 44.7 \\
\hline \multicolumn{9}{|l|}{ Level of education } \\
\hline illiterate & 0 & 0.0 & 11 & 40.7 & 6 & 22.2 & 10 & 37.1 \\
\hline$\leq 4$ years & 8 & 13.8 & 27 & 46.6 & 6 & 10.3 & 17 & 29.3 \\
\hline$>4$ years & 1 & 20.0 & 4 & 80.0 & 0 & 0.0 & 0 & 0.0 \\
\hline \multicolumn{9}{|l|}{ Income } \\
\hline$<2 \mathrm{MMW}$ & 5 & 8.2 & 28 & 46.0 & 9 & 14.7 & 19 & 31.1 \\
\hline$\geq 2 \mathrm{MMW}$ & 3 & 11.1 & 13 & 48.1 & 3 & 11.1 & 8 & 29.7 \\
\hline N/A & 1 & 50.0 & 1 & 50.0 & 0 & 0.0 & 0 & 0.0 \\
\hline
\end{tabular}

GEDoCh: Group for Studies into Chagas' disease, SD: sociodemographic, MMW: minimum monthly wage, N/A: information not available.

TABLE 2

Distribution of comorbidities in elderly chagasic patients interviewed in the GEDoCh Outpatient Unit.

\begin{tabular}{lcc}
\hline Comorbidities & Distribution & Percentage (\%) \\
\hline Systemic arterial hypertension & 51 & 56.7 \\
Osteoporosis & 21 & 23.3 \\
Osteoarthritis & 19 & 21.1 \\
Dyslipidemia & 18 & 20.0 \\
Ischemic heart disease & 9 & 10.0 \\
Diabetes mellitus & 9 & 10.0 \\
Dyspepsia & 9 & 10.0 \\
Heart failure & 7 & 7.78 \\
Hypothyroidism & 7 & 7.78 \\
\hline
\end{tabular}

GEDoCh: Group for Studies into Chagas' disease.

(64\%) was observed, while for men, the most frequent number of comorbidities was one, for which the incidence was $42.5 \%$. It should be noted that only dyspepsia, which was present in $17.5 \%$ of men and $4 \%$ of women, was more common in men than in women. There was also a variation in the number of comorbidities according to age group. Individuals aged 67 or under had a higher proportion of one $(30.8 \%)$ or two (27\%) concurrent illnesses, while those aged over 67 had a greater proportion of three (21\%) or four (18.4\%). The average number of comorbidities in individuals aged 67 or under was $2.5 \pm 1.6$; the corresponding figure for those over 67 was $3.2 \pm 2.0$. However, the differences between the total number of comorbidities for the various age groups was not statistically significant $(\mathrm{p}=0.119489)$.

When the patients were divided into two groups according to the number of comorbidities $(<4$ and $\geq 4)$, the mean number of concurrent diseases for women was $3.2 \pm 1.8$, and for men, $2.3 \pm 1.7(\mathrm{p}=0.006064)$. Among patients with $\geq 4$ comorbidities (Table 3), women predominated, with $42 \%$ being classified in this
TABLE 3

Number of comorbidities in elderly chagasic patients interviewed in the GEDoCh Outpatient Unit by gender and age group.

\begin{tabular}{|c|c|c|c|c|c|c|c|c|}
\hline \multirow[b]{3}{*}{ Comorbidities } & \multicolumn{4}{|c|}{ Gender } & \multicolumn{4}{|c|}{ Age Group } \\
\hline & \multicolumn{2}{|c|}{ male } & \multicolumn{2}{|c|}{ female } & \multicolumn{2}{|c|}{$\leq 67$ years-old } & \multicolumn{2}{|c|}{$>67$ years-old } \\
\hline & $\mathrm{n}$ & $\%$ & $\mathrm{n}$ & $\%$ & $\mathrm{n}$ & $\%$ & $\mathrm{n}$ & $\%$ \\
\hline$<4$ & 31 & 77.5 & 29 & 58.0 & 38 & 73.0 & 22 & 57.9 \\
\hline$\geq 4$ & 9 & 22.5 & 21 & 42.0 & 14 & 23.0 & 16 & 42.1 \\
\hline Total & 40 & 100 & 50 & 100 & 52 & 100 & 38 & 100 \\
\hline
\end{tabular}

GEDoCh: Group for Studies into Chagas' disease, UNICAMP.

category. The percentage of men with less than four concurrent illnesses was $77.5 \%$, while the corresponding figure for women was $58 \%(p=0.119489)$. Regarding age group, the mean number of concurrent illnesses for patients up to 67 years of age was 2.5 \pm 1.6 , while the corresponding figure for those above this age was $3.2 \pm 2.0(\mathrm{p}=0.119489)$.

The incidence of the most frequent illnesses varied according to the age group: SAH was present in $58.8 \%$ of individuals aged 67 or under, osteoarthritis in $52.6 \%$, DM in $55.5 \%$, dyspepsia in $66.7 \%$ and hypothyroidism in $57.1 \%$. The oldest patients presented with more ischemic heart disease $(88.9 \%)$, dyslipidemia (61.1\%), HF (85.7\%) and osteoporosis (57.1\%). Concerning the distribution of comorbidities by age group, a statistically significant difference was observed for ischemic heart disease $(\mathrm{p}=0.0038315)$ and HF $(\mathrm{p}=0.0209032)$ in individuals aged over 67. Cerebrovascular disease showed a tendency toward an association when individuals aged 60 to 67 were compared with those aged over 67 years $(p=0.06071263)$.

The number of hospitalizations was also examined and $17.8 \%$ of the subjects had been hospitalized at least once in the year prior to the interview. Decompensated heart failure was the cause of hospitalization in $68.7 \%$ of the patients. Other causes included cerebrovascular disease, pneumonia, pleural hemorrhage and surgery, which together accounted for $31.2 \%$ of all hospitalizations. The majority of individuals who had been admitted to hospital in the year prior to the interview were men $(56.3 \%)$; of these, $75 \%$ were aged over 67 years-old, $50 \%$ had attended school for up to four years and $81.3 \%$ had a monthly income of less than twice the minimum monthly wage. The predominant clinical forms of Chagas' disease were the cardiac (50\%) and mixed (37.5\%) forms.

The types of therapeutic agents most frequently used by the patients in our study were angiotensin-converting enzyme inhibitors (ACEIs), used by $46.7 \%$ of the subjects; diuretics (45.6\%); platelet aggregation inhibitors $(35.6 \%)$; proton pump inhibitors (22.2\%); and antiarrhythmic agents (20\%). Other medications used less frequently were $\mathrm{H}_{2}$ receptor antagonists, antidepressants, antidiabetic agents, calcium channel blockers, benzodiazepines and levothyroxine. Only $8.9 \%$ of the subjects used sodium alendronate, and $\mathbf{1 5 . 6 \%}$ calcium carbonate. The majority $(74.4 \%)$ of the patients reported using up to four medications a day. A total of $25.6 \%$ of the interviewees were receiving polypharmacotherapy. 


\section{DISCUSSION}

This study permitted a sociodemographic pattern to be identified for elderly Chagas' disease sufferers attended at the GEDoCh Outpatient Unit. The following groups predominated in the study population: women; patients between 60 and 69 years of age; widows and widowers; patients with a limited education; and retired patients. This profile may be associated with a cohort phenomenon involving people who live in very specific conditions that contribute to the appearance and development of the disease. According to Dias ${ }^{13}$, in the context of the political and social evolution in the South American continent, the presence of Chagas' disease in this population reflects the social inequality and poor conditions to which this population is exposed.

The profile detected in this study is similar to that of a cohort of elderly subjects living in an area endemic for Chagas' disease (Bambuí, MG) ${ }^{2629}$. In a survey by Lima-Costa et $a^{26}$, the following groups predominated: women $(60 \%)$; patients with a median age of 67 years-old; married patients $(48.9 \%)$; widows and widowers $(35.4 \%)$; patients with a monthly income between 1 and 2.99 times the minimum monthly wage (62\%); and patients who had only attended school for up to 4 years $(89.1 \%)$. According to $\mathrm{Neri}^{35}$, there are more elderly women than men and the former are financially worse off, less educated and in worse health than the latter. This situation represents what the literature on gerontology refers to as the feminization of ageing, which is a result of the greater life expectancy at birth and at 60,70 and 80 years of age ${ }^{3540}$. In general, old age represents a different experience for men and women, both subjectively and in terms of standard of living, diseases and death. However, the current literature concerning factors differentiating health in the elderly that addresses the issue of sex is still insufficient ${ }^{42}{ }^{43}$ ${ }^{48}$ for complete understanding of this phenomenon.

With regard to financial income, elderly individuals in Brazil have limited purchasing power, few pension benefits or allowances or even no income at all ${ }^{2}$. The majority of chagasic patients live in unhealthy conditions and sometimes have to work long hours to survive ${ }^{14}{ }^{18}$. In view of this, the social impact of the disease in terms of its repercussions for occupational health ${ }^{18}$ must be taken into account, as $81.3 \%$ of the elderly sufferers of the disease interviewed earned less than two minimum monthly wages.

Regarding education, $30 \%$ of the elderly chagasic patients were illiterate and the majority only had up to four years of education (64.4\%). In the study by Oliveira $e a b^{7}$, in which the mean age was 48.1 years-old, the majority of the participants had not completed primary school (68.6\%) and the percentage of illiterate individuals (27.9\%) was very similar to that in the present study. This is in part a reflection of the socioeconomic conditions of chagasic patients, who have few social opportunities, low wages and limited education. Dias ${ }^{14}$ explains that the disease is often associated with significant social losses in terms of mortality, inability to work and social and medical costs and that the socioeconomic context has allowed human Chagas' disease to spread.

The predominant clinical form among the elderly patients evaluated in this study was the cardiac form, followed by the mixed form, for which the incidence of megaesophagus was higher than that of megacolon. These findings are in agreement with the study by Almeida et $a l^{1}$, who verified the cardiac form of Chagas' disease in $88.5 \%$ of their chagasic patients. Chagasic cardiopathy is usually more common in men, as has been shown by a number of authors ${ }^{1717}$. Coelho Jr et al ${ }^{12}$ estimated that $30 \%$ of individuals infected by Trypanosoma cruzi in Brazil will develop this type of lesion. In the present study, $62.5 \%$ of the men had chagasic cardiopathy, showing the importance of studying elderly individuals, who will very likely show alterations as a result of chronic heart damage.

Although chronic chagasic cardiopathy is the most serious lesion caused by Chagas' disease, the mechanisms associated with the involvement of the heart remain poorly understood ${ }^{22} 31$. The majority of infected people remain asymptomatic and some $30 \%$ have heart and/or digestive complications in the late phase of the disease ${ }^{17}$. The most serious organic and functional myocardial damage manifests itself in only $10 \%$ of chagasic cardiac patients. This was observed to be true for the current study population, as $15.9 \%$ of the elderly subjects presented with the severe form of chagasic cardiopathy.

In addition, it is important to note that the elderly have higher morbidity indices than other age groups 3355565 . According to Miller et $\boldsymbol{b}^{33}$, the main diseases that affect these individuals are DM, chronic obstructive pulmonary disease, peripheral vascular disease, muscular-skeletal disorders, kidney and liver disorders, neoplasias and neurological diseases, as well as cardiovascular diseases (CVDs), which receive greater attention. The literature on this subject emphasizes that CVDs are the main cause of death and morbidity in the elderly and are responsible for 18 million deaths annually worldwide ${ }^{565458}$. Generally speaking, the main heart diseases that affect the elderly are HF, coronary disease, hypertrophic cardiomyopathy, heart valve disease, supraventricular and ventricular arrhythmia and $\mathrm{SAH}^{54}$. In the present study, the following cardiovascular diseases were the most common observed: SAH, HF and ischemic heart disease.

In a study of 4,710 elderly non-chagasic North American patients between 1999 and 2004, Ostchega et al ${ }^{39}$ verified that $67 \%$ of the elderly patients were suffering from hypertension, $60 \%$ of whom were aged between 60 and 69 years-old and $72 \%$ of whom were women. This finding is of great importance and is corroborated by Lima-Costa et $a l^{25}$ who reported that SAH was the most common chronic disease in the elderly population in their study, $61.5 \%$ of whom were suffering from hypertension. In a multicenter study of a non-chagasic population, Taddei et $_{a} \mathrm{l}^{3}$ determined a high prevalence of SAH (67\%), as well as ischemic heart disease (29\%), arrhythmias (18\%), cardiomyopathy (11\%) and $\mathrm{HF}(10 \%)$.

Particularly noteworthy is the high percentage of SAH among elderly sufferers of Chagas' disease. Almeida et al reported a high incidence of SAH among elderly chagasic patients (39.3\%). Guariento et al $^{19}$ investigated chronic illnesses that coexisted with Chagas' disease in a reference service. Their results showed that $51.6 \%$ of their patients had SAH, $22.3 \%$ had other heart diseases arising from causes other than Trypanosoma cruzi infection, 
19.4\% had dyspepsia, 17.3\% had some kind of anxiety disorder, $11.5 \%$ had chronic lung disease and $11.1 \%$ were obese $^{16}$. While analyzing 95 chronic chagasic patients between 22 and 89 years of age at Maringá University Hospital, PR, Bozelli et al observed that SAH, DM and chronic obstructive lung disease, among others, coexisted with Chagas' disease in $25.3 \%, 10.5 \%$ and $4.2 \%$ of their patients, respectively. Kamiji and Oliveira ${ }^{24}$ verified DM, chronic kidney failure, neoplasias and Parkinson's disease in the chagasic group they studied.

Guariento et $\mathrm{al}^{17}$ investigated the clinical interaction between Chagas' disease and SAH and observed that greater myocardial damage occurred in patients with this combination of diseases (56\%). They also determined that more serious forms of heart disease occurred in chagasic patients suffering from hypertension than in those who did not have hypertension. Bertanha et al ${ }^{6}$ studied the characteristics of 125 chagasic patients over the age of 25 years-old who had been attended at the Clinic Hospital of Campinas State University. In their study, $55.2 \%$ of the patients had $\mathrm{SAH}$; these were older and predominantly women and had greater heart damage, such as cardiac conduction disorders, extrasystoles and left ventricular overload.

Added to this are physiological changes due to cardiovascular ageing and the more common comorbidities among the elderly, which contribute to impairment of heart function and to clinical repercussions, such as hospitalization and functional decline, as well as to a reduction in the quality of life $\mathrm{e}^{2531}$ and the increased biopsychosocial vulnerability inherent to chronic processes ${ }^{8}$. All these factors can lead to increased morbidity and mortality and a reduction in the quality of life for chronic elderly patients suffering from Trypanosoma cruzi infection ${ }^{11}{ }^{12}$.

Furthermore, the prevalence of cardiovascular diseases, especially ischemic heart disease and cerebrovascular disease, in the elderly population as a whole is known to be increasing ${ }^{3038} 49$ and remains an important cause of morbidity and mortality in this population ${ }^{49}$. A study of necropsies of patients aged 90 years-old or over verified that $70 \%$ of these had blocked coronary vessels, leading the authors to conclude that age is an independent factor for coronary disease ${ }^{54}$. Another study of necropsies in 92 elderly chagasic patients found that SAH (37\%), arteriosclerosis (62\%) and ischemic heart disease $(6.5 \%)$ were also present ${ }^{36}$, showing the overlap between these and Chagas' disease.

In this study, there was significant expression of CVDs in the chagasic population. Ischemic heart disease was observed in a total of $10 \%$ of the study population, which agrees with other studies in which this index was between 9 and $15 \%^{54}$. Coronary disease is in turn the cause of 70 to $80 \%$ of deaths among both men and women ${ }^{50}{ }^{54}$. It should be noted that SAH and dyslipidemia, which are observed in $56.7 \%$ and $20 \%$ of elderly chagasic patients, respectively, are important factors in the onset and development of both ischemic heart disease and cerebrovascular disease. SAH is the main risk factor for coronary disease, HF and cerebrovascular disease in the elderly and is considered an independent cardiovascular factor ${ }^{33} 34$.

Studies have shown that HF is a frequent cause of hospitalization, morbidity and mortality among the elderly ${ }^{3349} 5054$.
In a study of non-chagasic patients, Taddei et $a l^{33}$ reported a lower percentage of hospitalizations (14\%), of which $\mathrm{HF}$ accounted for $31 \%$ and coronary insufficiency $25 \%$, while in a study of mortality and hospitalizations among elderly Brazilians, Lima-Costa et $a^{28}$ observed that diseases of the circulatory system, neoplasias and respiratory diseases were the main causes of death in public health services between 1980 and 1996. Diseases of the circulatory and respiratory systems accounted for half of the hospitalizations and HF was associated with the highest percentage of hospitalizations among the elderly (13.6\%).

In light of this, HF syndrome has been considered a primarily geriatric problem that has become an important public health problem in the $21^{\text {st }}$ century due to population ageing ${ }^{46}$. With regard to chronic chagasic cardiopathy, a recent study reported that complications may include arrhythmias, cardiomegaly, HF and death and that this condition is an important cause of hospitalization and increased mortality associated with clinical decompensation ${ }^{12}$.

Among infectious and parasitic diseases, Chagas' disease represents the second most frequent cause of death among elderly Brazilians. Mortality among these individuals is due to a cohort effect, as a result of exposure to Trypanosoma cruzi infection in the past. The fact that Chagas' disease is an important cause of death among elderly Brazilians indicates that the consequences of infection are still being felt among a segment of this population ${ }^{28}$.

It is important to remember that a significant number of the elderly in the present study population were suffering from the cardiac form of the disease. In addition to the functional alterations inherent to ageing of the cardiovascular system, these patients are also subject to the damage associated with chagasic cardiopathy and other cardiovascular diseases, such as SAH and ischemic cardiopathy, and are consequently more vulnerable to clinical decompensation or the development of lesions in organs, such as the brain, kidneys or the heart itself.

Currently, the survival of patients with Chagas heart disease has increased, which may characterize the condition of survivors. It is noteworthy that in Brazil, the performance of heart transplantation and implantation of pacemakers by the Brazilian Public Health System (SUS) has increased. This is even cited as one of the reasons to explain the increased survival of Chagas in Brazil ${ }^{14}$.

Another group of diseases that predominated among the study population were osteoarticular diseases, of which the most notable were osteoporosis (23.3\%) and osteoarthritis (21.1\%). Ageing is known to increase the predisposition to osteoarticular diseases ${ }^{33}$ and osteoarthritis and osteoporosis are among the main causes of morbidity among the elderly ${ }^{3053}$. Osteoporosis is notable as it becomes more common with increasing age and represents a risk factor for skull fractures or trauma following a fall, leading to increased morbidity and mortality in the elderly ${ }^{42} 4455657$.

The most commonly used therapeutic agents were consistent with the clinical status of our elderly chagasic population, since the cardiac and mixed forms of the disease predominated in this study. The following medications were being used: ACEIs (46.7\%), 
diuretics (45.6\%), platelet aggregation inhibitors (35.6\%) and antiarrhythmic agents $(20 \%)$. The finding that cardiovascular medication was being widely used by the elderly participants as a whole is consistent with the findings of other studies ${ }^{2021}$. In spite of the significant percentage of elderly patients with osteoporosis (23.3\%), few were taking medication for this condition $(8.9 \%$ alendronate and $15.6 \%$ calcium carbonate).

Polypharmacy is an important issue among the geriatric population as a whole, as corroborated by $\mathrm{Garcia}^{16}$ in a study that observed this condition in $32 \%$ of non-chagasic individuals. In addition, it should be borne in mind that elderly people's bodies undergo changes in their physiological functions that must be taken into account if the prescription is to be both rational and effective $^{301632}$.

A total of $77.5 \%$ of the men in the present study had up to four comorbidities, and in $42 \%$ of the elderly women four or more illnesses coexisted with Chagas' disease. According to Rabelo and Cardoso ${ }^{42}$, chronic diseases are of particular interest in gerontological studies because they are influenced by medical, psychological and social factors ${ }^{42}$. For Romero ${ }^{48}$, the state of health declared by the elderly can to a great extent be explained by sex. Men are less likely to "declare themselves to be sick" than women. However, one aspect that deserves further investigation is the fact that men seek medical help less often ${ }^{39}{ }^{46}$. This may to some extent be related to the differences between the sexes in so far as behavior in relation to health is concerned ${ }^{48}$ and could explain the greater severity and more lethal nature of Chagas' disease in men (particularly those with myocardial damage) reported in some studies ${ }^{4}$.

It can be concluded, therefore, that elderly chagasic patients are a particularly vulnerable population when the harmful effects of a combination of Chagas' disease and other chronic degenerative diseases are taken into consideration. Such diseases can cause severe morbidity as a result of damage to the cardiovascular system, a risk which is aggravated by polypharmacy. Finally, it is essential to highlight that the majority of chagasic patients are females. This phenomenon is known in the literature on gerontology as the process of the feminization of ageing. Such women, however, are at a disadvantage compared with men, as they not only are poorer and less educated, but also have more comorbidities and use a greater number of drugs.

\section{REFERENCES}

1. Almeida EA, Barbosa Neto RM, Guariento ME, Wanderley JS, Souza ML. Apresentação clínica da doença de Chagas crônica em indivíduos idosos. Revista da Sociedade Brasileira de Medicina Tropical 40:311-315, 2007.

2. Alves LC, Rodrigues RN. Determinantes da autopercepção de saúde entre idosos do município de São Paulo, Brasil. Revista Panamericana de Saúde Pública 17:333-340, 2005.

3. Anderson GM, Beers MH, Kerluke K. Auditing prescription practice using explicit criteria and computerized drug benefit claims data. Journal of Evaluation in Clinical Practice 3:283-294, 1997.

4. Barreto ACP, Arteaga E, Mady C, Ianni BM, Bellatti G, Pileggi F. Sexo masculino. Fator prognóstico na doença de Chagas. Arquivos Brasileiro de Cardiologia 60: 225-227, 1993
5. Beaghole R, Saraci R, Panico S. Cardiovascular diseases: causes, surveillance and prevention. International Journal Epidemiology 30:1-4, 2001.

6. Bertanha L, Guariento ME, Magna LA, Almeida EA. Caracterização clínicolaboratorial de chagásicos hipertensos sem insuficiência cardíaca manifesta. Revista da Sociedade Brasileira de Medicina Tropical 41:163-168, 2008.

7. Borges-Pereira J, Zauza PL, Galhardo MC, Nogueira JS, Pereira GROL, Cunha RV. Doença de Chagas na população urbana do distrito sanitário de Rio Verde, Mato Grosso do Sul, Brasil. Revista da Sociedade Brasileira de Medicina Tropical 34:459-466, 2001.

8. Bozelli CE, Araújo SM, Guilherme ALF, Gomes ML. Perfil clínico-epidemiológico de pacientes com doença de Chagas no Hospital Universitário de Maringá, Paraná, Brasil. Cadernos de Saúde Pública 22:1027-1034, 2006.

9. Canesqui AM. A hipertensão do ponto de vista dos adoecidos. In: Canesqui AM (org) Olhares socioantropológicos sobre os adoecidos crônicos. Editora Hucitec, FAPESP, São Paulo, p.87-110, 2007.

10. Carlson JE. Perils of polypharmacy: 10 steps to prudent prescribing. Geriatrics 51:26-35, 1996.

11. Carvalho Filho ET, Figueira JC, Pasini U, Forti NA, Curiati JAE, Ferreira MLM, Serro Azul LG. Aspectos da doença de Chagas no idoso. Arquivos Brasileiros de Cardiologia 45:102-107, 1985.

12. Coelho Jr AMP, Novaes ES, Ferreira E, Neves MAS, Cassini PVS, Duarte TMH, Dias AOD, Santos MS, Pereira MC, Rocha MOC. Cardiopatia chagásica como principal etiologia de ICC em pacientes internados no HC-UFMG. In: Resumos da XXIII Reunião Anual de Pesquisa Aplicada em Doença de Chagas, Uberaba - MG, 2007.

13. Dias JCP. O Controle da Doença de Chagas nos Países do Cone Sul da América: História de uma iniciativa internacional 1991-2001. In: Silveira AC (org) 0 Controle da Doença de Chagas nos Países do Cone Sul da América: História de uma iniciativa internacional 1991-2001. Organização Pan-Americana da Saúde, Brasília, p.145-250, 2001.

14. Dias JCP. Globalização, iniqüidade e doença de Chagas. Cadernos de Saúde Pública, 23 (sup 1): S13-S22, 2007.

15. Francisco PMSB, Donalísio MR, Barros MBA, César CLG, Carandina L, Goldbaum M. Fatores associados à doença pulmonar em idosos. Revista de Saúde Pública 40:428-435, 2006.

16. Garcia JT. Uso de medicamentos. In: Ramos LR, Toniolo Neto J (orgs) Guias de Medicina Ambulatorial e Hospitalar UNIFESP - Escola Paulista de Medicina. Geriatria e Gerontologia. Editora Manole, São Paulo, p.27-36, 2005.

17. Guariento ME, Alegre SM, Almeida EA, Wanderley JS. Doença de Chagas e enfermidades associadas em um serviço de referência. Revista da Sociedade Brasileira de Medicina Tropical 35 (sup 3):206-207, 2002.

18. Guariento ME, Camilo MVF, Camargo AMA. Working conditions of Chagas' disease patients in a large Brazilian city. Cadernos de Saúde Pública 15:381-386, 1999

19. Guariento ME, Orosz JEB, Gontijo JAR. Interação clínica entre moléstia de Chagas e Hipertensão Arterial Primária em um serviço de referência ambulatorial. Arquivos Brasileiros de Cardiologia 70:431-434, 1998.

20. Gurwitz JH, Field TS, Harrold LR, Rothschild J, Debellis K, Seger AC, Cadoret C, Fish LS, Garber L, Kelleher M, Bates DW. Incidence and preventability of adverse drug events among older persons in the ambulatory setting. Journal of American Medical Association 289:1107-1116, 2003.

21. Hershman DL, Simonoff PA, Frishman WH, Preston F, Aronson MK. Drug utilization in the old and how it relates to self-perceived health and all-cause mortality: results from the Bronx Aging Study. Journal American Geriatrics Society 43:356-360, 1995.

22. Higuchi ML, Benvenuti LA, Reis MM, Metzger M. Pathophysiology of the heart in Chagas's disease: current status and new developments. Cardiovascular Research 60:96-107, 2003

23. Hueb MFD, Loureiro SR. Revisão: Aspectos cognitivos e psicossociais associados a doença de Chagas. Psicologia em Estudo 10:137-142, 2005.

24. Kamiji MM, Oliveira RB. 0 perfil dos portadores de doença de Chagas, com ênfase na forma digestiva, em hospital terciário de Ribeirão Preto, SP. Revista da Sociedade Brasileira de Medicina Tropical 38:305-309, 2005.

25. Lima-Costa MF, Barreto SM, Giatti L. Condições de saúde, capacidade funcional, uso de serviços de saúde e gastos com medicamentos da população idosa 
brasileira: um estudo descritivo baseado na Pesquisa Nacional por Amostra de Domicílios. Cadernos de Saúde Pública 19:735-743, 2003.

26. Lima-Costa MF, Barreto SM, Guerra HL, Firmo JOA, Uchoa E, Vidigala PG. Ageing with Trypanosoma cruzi infection in a community where the transmission has been interrupted: the Bambuí Health and Ageing Study (BHAS). International Journal of Epidemiology 30:887-893, 2001.

27. Lima-Costa MF, Firmo JOA, Uchôa E. A estrutura da auto-avaliação da saúde entre idosos: Projeto Bambuí. Revista de Saúde Pública 38:827-834, 2004.

28. Lima-Costa MF, Peixoto SV, Giatti L. Tendências da mortalidade entre idosos brasileiros (1980-2000). Epidemiologia e Serviços de Saúde 13:217-228, 2004

29. Lima-Costa MF, Uchoa E, Guerra HL, Firmo JOA, Vidigal PG, Barreto SM. The Bambuí health and ageing study (BHAS): methodological approach and preliminary results of a population-based cohort study of the elderly in Brazil. Revista de Saúde Pública 34:126-135, 2000.

30. Linhares CRC, Coelho VLD, Guimarães RM, Campos APM, Carvalho NT. Perfil da clientela de um ambulatório de geriatria do Distrito Federal. Psicologia: Reflexão e crítica 16:319-326, 2003

31. Magnani C, Oliveira BG, Gontijo ED. Representações, mitos e comportamentos do paciente submetido ao implante de marcapasso na doença de Chagas. Cadernos de Saúde Pública 23:1624-1632, 2007

32. Medeiros-Souza P, Santos-Neto LL, Kusano LTE, Pereira MG. Diagnosis and control of polypharmacy in the elderly. Revista de Saúde Pública 41:1049-1053, 2007.

33. Miller KE, Zylstra RG, Standridge JB. The geriatric patient: a systematic approach to maintaining health. In: American Academy of Family Physicians; Acesso em 15/11/2006, p. 1-13. http://www.aafp.org/afp; 25/07/2001.

34. Mulrow CD, Brand MB. Hypertension in the elderly. In: Gallo JJ, Busby-Whitehead J, Rabins PV, Silliman RA, Murphy JB (eds). Reichel's care of the elderly: clinical aspects of aging, $5^{\text {th }}$ edition. Philadelphia: Lippincott Williams \& Wilkins, p.129$140,1999$.

35. Neri AL. Desenvolvimento eEnvelhecimento: perspectivas biológicas, psicológicas e sociológicas. 2 edição, Editora Papirus, Campinas, São Paulo, p.161-200, 2006.

36. Oliveira FA, Reis MA, Teixeira PA. A cardiopatia chagásica em idosos necropsiados. Revista da Sociedade Brasileira de Medicina Tropical 34:161-162, 2001.

37. Oliveira FAZ, Bicalho GVC, Souza Filho LD, Silva MJ, Gomes Filho ZC. Características epidemiológicas dos pacientes com Doença de Chagas. Revista Brasileira de Medicina de Família e Comunidade 6:107-113, 2006.

38. Organización Panamericana de la Salud. Aspectos clínicos de la enfermedad de Chagas. Informe de una reunión conjunta OMS/OPAS de investigadores. Organización Mundial de la Salud Boletín de la Oficina Sanitaria Panamericana 76: $141-158,1974$

39. Ostchega Y, Dillon CF, Hughes JP, Carroll M, Yoon S. Trends in Hypertension Prevalence, Awareness, Treatment, and Control in Older U.S. Adults: Data from the National Health and Nutrition Examination Survey 1988 to 2004. Journal of the American Geriatrics Society 55:1056-1065, 2007.

40. Papaléo Netto M, Yuaso DR, Kitadai FT. Longevidade: desafio no terceiro milênio. Mundo da Saúde 29:594-606, 2005.

41. Pinheiro JES, Freitas EV. Promoção da Saúde. In: Py L, Pacheco JL, Martins de Sá JL, Goldman SN (orgs) Tempo de Envelhecer - Percursos e Dimensões Psicossociais. Editora Setembro, Holambra, São Paulo, 2006.
42. Rabelo DF, Cardoso CM. Auto-eficácia, doenças crônicas e incapacidade funciona na velhice. PsicoUSF, p. 75-81, 2007. Acessado em 7/11/2007, http://scielo.bvspsi.org.br. ISSN 1413-8271.

43. Rahman MO. Age and gender variation in the impact of household structure on elderly mortality. International Journal of Epidemiology 28:485-491, 1999.

44. Ramos LR, Garcia JT. Terapêutica medicamentosa no idoso. In: Atualização Terapêutica 2003: manual prático de diagnóstico e tratamento. Artes Médicas, São Paulo: p.555-558, 2003

45. Ray WA, Griffin MR, Schaffner W, Baugh DK, Melton J. Psychotropic drug use and the risk of hip fracture. New England Journal of Medicine 316:363-369, 1987.

46. Rich MW. Heart failure in the $21^{\text {st }}$ century: a cardiogeriatric syndrome. Journa of Gerontology Series A: Biological Sciences and Medical Sciences 56:M88-M96, 2001

47. Rocha MOC, Correia PC, Barros MVL, Torre RM, Ribeiro ALP, Teixeira MM Cardiovascular function in elderly patients with chronic chagasic cardiopathy. Revista da Sociedade Brasileira de Medicina Tropical 36:545-550, 2003.

48. Romero DE. Diferenciais de gênero no impacto do arranjo familiar no status de saúde dos idosos brasileiros. Ciência \& Saúde Coletiva 7:777-794, 2002.

49. Ruijter W, Westendorp RGJ, Macfarlane PW, Jukema JW, Assendelft WJJ, Gussekloo J. The Routine Electrocardiogram for Cardiovascular Risk Stratification in Old Age: The Leiden 85-Plus Study. Journal American of Geriatric Society 55:872-877, 2007.

50. Shye D, Mullooly JP, Freeborn DK, Pope CR. Gender differences in the relationship between social network support and mortality: a longitudinal study of an elderly cohort. Social Science and Medicine 41:935-947, 1995.

51. Silveira AC. O Controle da Doença de Chagas nos Países do Cone Sul da América: História de uma iniciativa internacional 1991-2001. In: Silveira AC (org) 0 Controle da Doença de Chagas nos Países do Cone Sul da América: História de uma iniciativa internacional 1991-2001. Organização Pan-Americana da Saúde, Brasília, p.15-43, 2002.

52. Steinman MA, Rosenthal GE, Landefeld CS, Bertenthal D, Sen S, Kaboli PJ. Conflict and concordance between measures of medication prescribing quality. Medical Care 45:95-99, 2007

53. Taddei CFG, Ramos LR, Moraes JC. Estudo multicêntrico de idosos atendidos em ambulatórios de cardiologia e geriatria de instituições brasileiras. Arquivos Brasileiros de Cardiologia 69:327-333, 1997

54. Tresch DD. The clinical diagnosis of heart failure in older patients. Journal American Geriatric Society 45:1128-1133, 1997.

55. Veras RP. Modelos contemporâneos no cuidado à saúde: novos desafios em decorrência da mudança do perfil epidemiológico da população brasileira. Revista da Universidade de São Paulo 51:72-85, 2001

56. Veras RP. Em busca de uma assistência adequada à saúde do idoso: revisão da literatura e aplicação de um instrumento de detecção precoce e de previsibilidade de agravos. Cadernos de Saúde Pública 19:705-715, 2003.

57. World Health Organization Study Group. Consensus Development Conference Diagnosis, Prophylaxis, and Treatment of Osteoporosis. American Journal Medicine 94:646-650, 1993.

58. Zaslavsky C, Gus I. Idoso. Doença Cardíaca e Comorbidades. Arquivos Brasileiros de Cardiologia 79:635-639, 2002 